Short notes and reviews

\title{
First record of a Tachaea species from Sulawesi (Indonesia) with description of its manca stage (Isopoda, Flabellifera, Corallanidae)
}

\author{
Thomas E. Bowman ${ }^{1} \&$ Lazare Botosaneanu ${ }^{2}$ \\ ${ }^{1}$ Department of Invertebrate Zoology (Crustacea), NHB 163 Smithsonian Institution, Washington, DC \\ 20560, USA; ${ }^{2}$ Department of Entomology, Institute of Taxonomic Zoology, University of Amsterdam, \\ Plantage Middenlaan 64, 1018 DH Amsterdam, The Netherlands
}

Keywords: Isopoda Corallanidae, Tachaea, taxonomy, distribution, ecology, Sulawesi

\begin{abstract}
A corallanid isopod in the manca stage (lacking pereopod 7), collected from alluvial gravel along the Batui River in Sulawesi, Indonesia, and identified questionably as Tachaea lacustris Weber, 1892, is illustrated and described in detail. Tachaea lacustris was known previously only from freshwater lakes in Sumatra and Java. Its presence in river alluvial gravel should not be interpreted as possible adaptation to the hyporheic habitat.
\end{abstract}

The flabelliferan isopod family Corallanidae contains six genera, including the genus Tachaea Schioedte \& Meinert, 1879. Six species of Tachaea have been described, and two more were added when Austroargathona Riek, 1953, was reduced to a junior synonym of Tachaea by Delaney (1989). Tachaea leopoldi Nierstrasz, 1930, was transferred to Corallana by Bruce (1982), and Stebbing (1907) argued that $T$. incerta Hansen, 1890, is an adult female of $T$. crassipes, described by Hansen from a single juvenile specimen. This leaves Tachaea with 6 currently recognized species, summarized in Delaney (1989).

Of the six species, only $T$. spongillicola Stebbing, 1907 , is readily distinguished from its congeners; its pleotelson is more broadly rounded and the terminal segment of the maxilliped is more elongate than in other Tachaea spp. The other five species are so similar and exhibit so much intraspecific variability (see discussion in Delaney, 1989), that we do not believe they can be distinguished with confidence from available descriptions and illustrations.
The specimen from Sulawesi (= Celebes) described herein exhibits some differences from published descriptions of Tachaea spp., but because these differences might be associated with its immaturity, we have chosen not to designate it a new species, but to assign it questionably to $T$. lacustris Weber, 1892, the only species known to occur in Indonesia (Sumatra and Java). We give detailed illustrations and a full description to aid future taxonomists in assigning it to the correct species.

Tachaea cf. lacustris Weber, 1892

(Figs. 1-24)

Tachaea lacustris Weber, 1892: 551-553, no figs.; Stebbing, 1908: 107; Thielemann, 1910: 22 [compared with $T$. chinensis Thielemann]; Nierstrasz \& De Marees van Swinderen, 1931: 397-399, figs. 1-3; Delaney, 1989: 55-56, figs. 36-37 [scanning electron micrographs of mouthparts].

Material. - Indonesia, central Sulawesi, lower course of Batui River, (S.W. of Luwuk: $01^{\circ} 09^{\prime} \mathrm{S}, 122^{\circ} 31.5^{\prime} \mathrm{E}$ ), leg. J. P. Duffels, 19 October 1989, from shallow hole dug with shovel in alluvial gravel of the river: 1 manca stage juvenile lacking 7 th pereopods, $3.9 \mathrm{~mm}$ in length. Specimen deposited in the National Museum of Natural History, Smithsonian Institution, catalog no. USNM 251331.

Description. - Body length $3.9 \mathrm{~mm}$, slightly more than twice body width $(1.8 \mathrm{~mm})$. Head slightly longer than and slightly immersed in pereonite 1 , anteriorly with short, broadly rounded rostrum; 

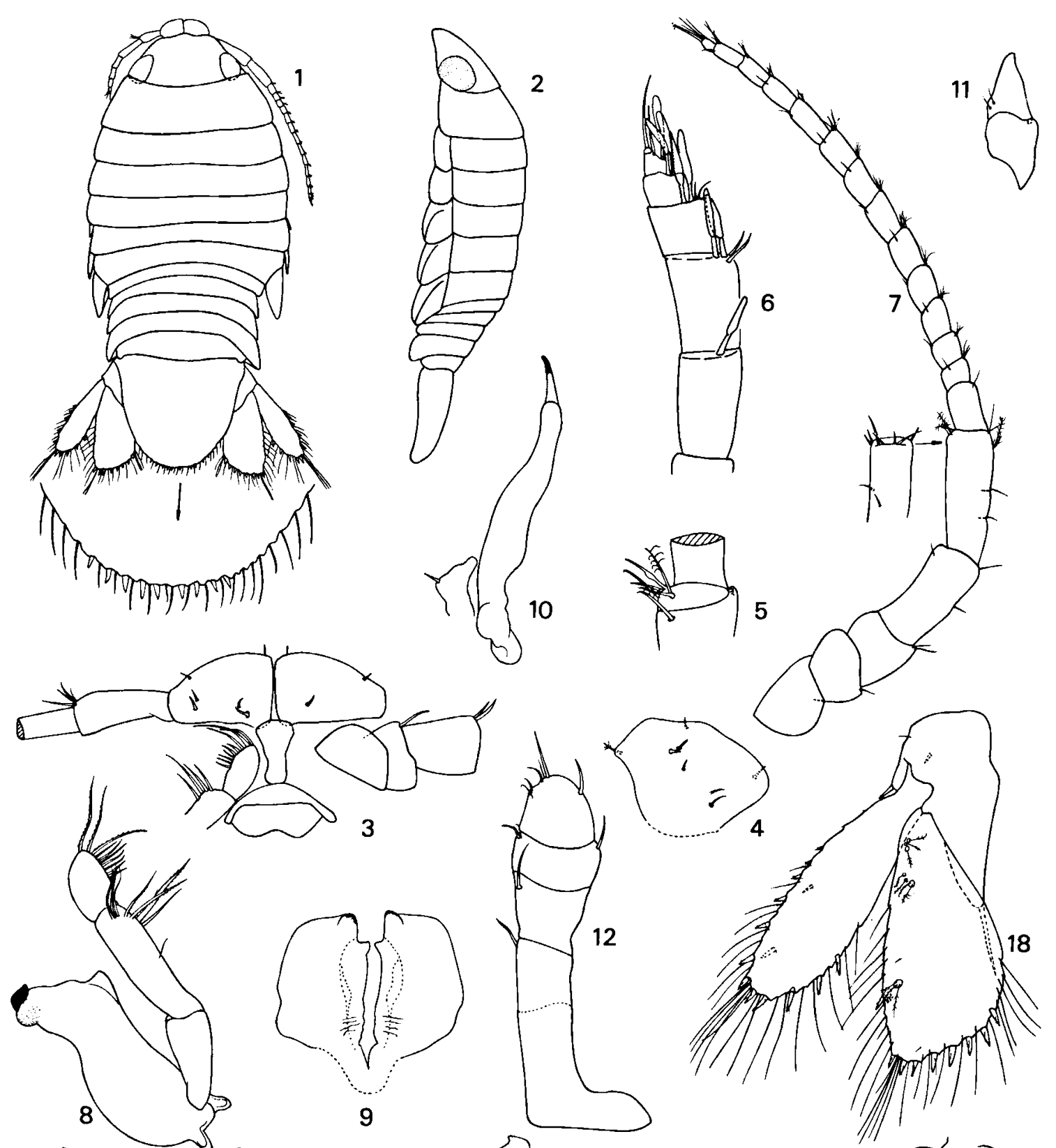

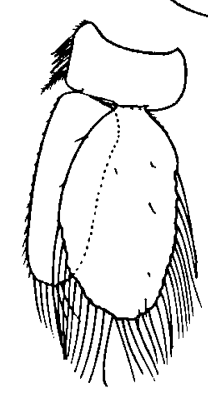

13

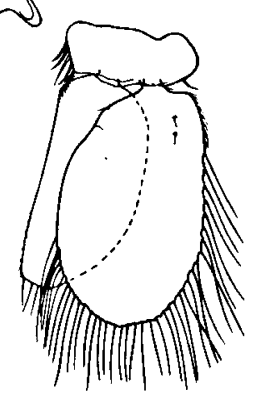

14

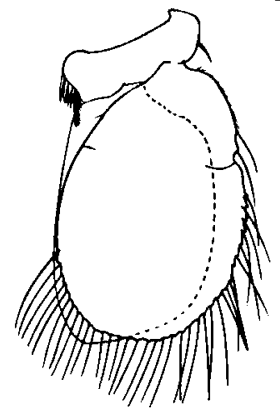

15

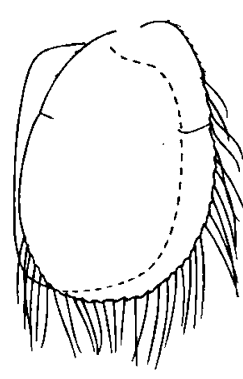

16

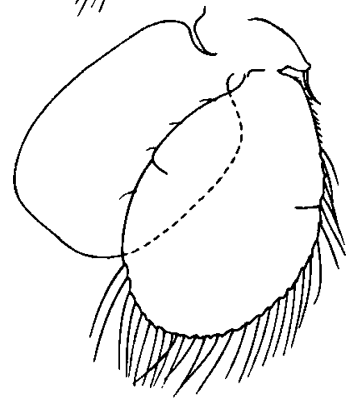

17 

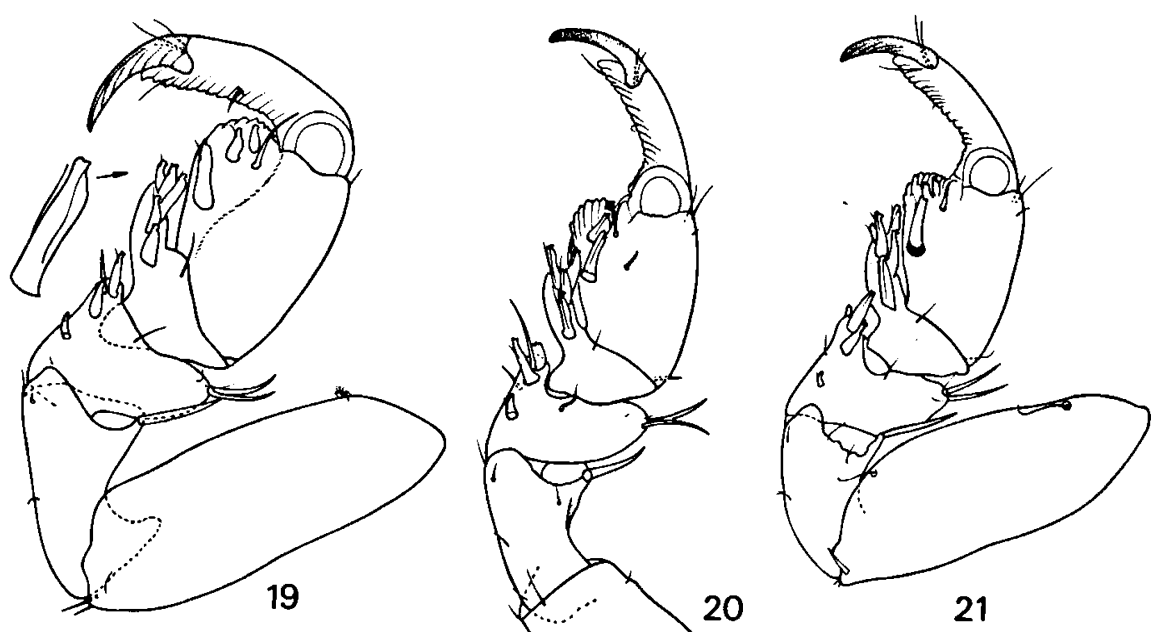

21

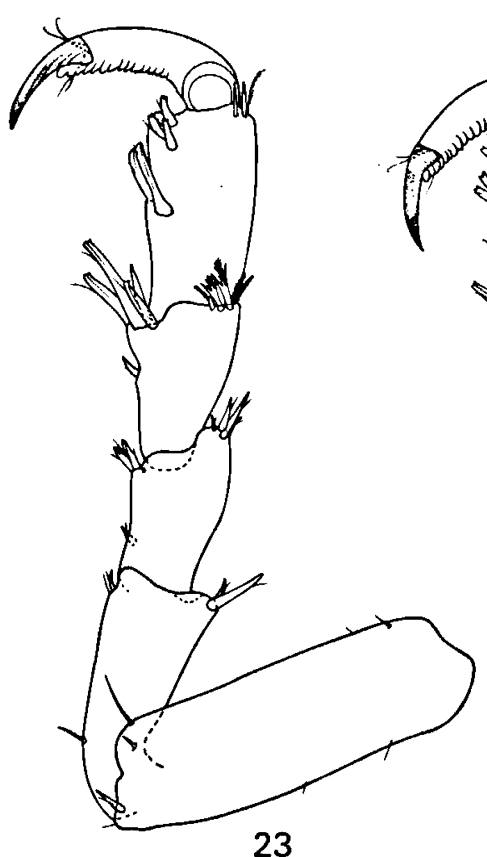

23

eyes well developed, oval, about half length of head. Pereonites $2-4$ subequal in length, about $2 / 3$ of length of pereonite 1; pereonites 5 and 6 distinctly shorter in dorsal but not in lateral view; pereonite 7 very short, without pereopods. Pleonites $2-5$ visible, subequal in length; pleonite 4 expanded ventrolaterally into rounded lobe overlapping much of pleonite 5. Pleotelson linguiform, $1 / 4$ longer than pleon, 0.8 as long as width at base; posterior margin with 21 setae and 9 spines about half as long as setae.

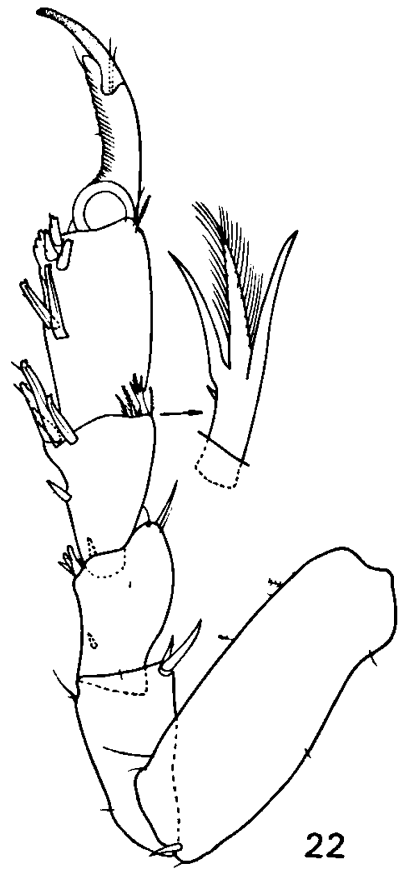

Figs. 1-24. Tachaea cf. lacustris Weber, 1892, manca stage: 1, habitus, dorsal (with more enlarged view of posterior margin of telson); 2, habitus, lateral; 3, ventral view of head, showing buccal area; 4, 1st segment of peduncle of left antenna 1, dorsal; 5 , chaetotaxy of distal part of 2nd segment of peduncle of right antenna 1 , dorsal; 6, segments $2-7$ of flagellum of antenna $1 ; 7$, left antenna 2, dorsal (with distal part of segment 5 of peduncle in ventral view); 8 , left mandible, ventral; 9, labium; 10 , left maxilla 1, ventral; 11 , left maxilla 2 , ventral; 12 , left maxilliped, ventral; 13-17, left pleopods $1-5$ (all setae are plumose); 18 , left uropod, dorsal (all setae are plumose); 19-24, left pereopods 1-6, lateral (pereopod 6 without basis).

Antenna 1 reaching nearly to midlength of pereonite 1; peduncle 2-segmented, segment 1 enlarged, segment 2 cylindrical, about 3 times as long as segment 1; flagellum 7-segmented; segment 1 about as long as peduncle segment 2 , segments 2 and 3 subequal, about half length of segment 1 , segments 4-7 successively shorter, segments $2-6$ with $1,2,2,2,1$ aesthetes, respectively. Antenna 2 reaching to about midlength of pereonite 4; peduncle segments sparsely armed with setae, segment 5 about $1 / 8$ longer than segment 4 ; flagellum 14-seg- 
mented, each segment with setal cluster at distolateral corner, and single seta near distomedial corner in segments $3,5,7,10,13$, latter seta near midwidth in segments $2,4,6,8,9,11$; segment 14 with 6 slender apical setae and 1 longer and thicker apical seta (broken in this specimen).

Frontal lamina obovate, narrowing posteriorly. Clypeus short, with narrow lateral arms overlapping labrum. Labrum well developed, with emarginate posterior margin.

Mandible with monocuspid incisor, lacinia and molar lacking; relative lengths of segments $1-3$ of palp 33 : $47: 20$ (=100); segment 1 unarmed, segment 2 with short seta at midlength and curved row of longer setae distally, segment 3 with 10 setae on lateral margin, of which 3 distal setae longer than others.

Labium with 2 short blunt teeth distomedially on each lobe; distal tooth larger.

Maxilla 1: lateral lobe elongate, with single slightly curved strong apical spine; medial lobe expanded distally into truncate apex with single seta on distomedial corner. Maxilla 2 two-segmented; segment 1 quadrate, unarmed; segment 2 triangular, with 2 short setae near proximal end of medial margin.

Maxilliped: palp 3-segmented, with sparse setation as illustrated.

Pereopods 1-3 prehensile; merus, carpus, and propus produced posteriorly into lobes armed with groups of stocky spines, lobe of carpus longest, lobe of propus broadest and corrugate; posterior edge of dactylus forming a corrugate lamina.

Pereopods 4-6 ambulatory and prehensile; merus, carpus, and propus with groups of stocky spines at anterodistal and posterodistal corners, some of those on posterodistal corners tridentate; anterior edge of dactylus corrugate.

Pleopods 1-4 with 4-5 retinacula on protopods; rami unsegmented, but exopods of pleopods 2-5 with partial sutures; endopod of pleopod 1 with 6 marginal setae, of pleopod 2 with 3 marginal setae, of pleopods 3-5 without marginal setae; exopods and endopods 1-2 transparent, endopods 3-5 opaque.

Uropods reaching slightly beyond pleotelson; endopod pyriform, slightly longer than and about $\mathbf{1 . 5}$ times as wide as oblong exopod; margins of both rami armed with plumose setae and spines.

Discussion. - Tachaea lacustris is known only from freshwater lakes in two Indonesian islands, Lake Singkarak in Sumatra, and Lakes Lamongan, Pakis, and Klakah in Java (Weber, 1892; Nierstrasz \& De Marees van Swinderen, 1931; Delaney, 1989). If our identification is correct, it extends the range by more than $1200 \mathrm{~km}$ to a third Indonesian island, Sulawesi.

The family Corallanidae Hansen, 1890 , is mainly present in tropical and subtropical shallow-water marine habitats. Tachaea is the exception, all its species but one being confined to tropical/subtropical freshwater habitats (lakes, ponds, rivers) in the Indo-West Pacific. Tachaea species frequent cryptic habitats; for instance, $T$. lacustris was also found (in Lake Singkarak, Sumatra, cf. Nierstrasz \& De Marees van Swinderen, 1931) burrowing "in Bohrgängen der Ephemeridenlarve Povilla corporaali Lestage in Baumstämmen, die im Uferwasser liegen". The presence of this species in alluvial gravel on the banks of a river is, thus, no surprise, and should not be considered as indicating an (incipient) adaptation to the hyporheic habitat.

\section{References}

Bruce, N.L., 1982. On the genus Corallana Dana, 1852 (Isopoda, Corallanidae) with description of a new species from western Australia. Crustaceana, 42: 241-249.

Delaney, P.M., 1989. Phylogeny and biogeography of the marine isopod family Corallanidae (Crustacea, Isopoda, Flabellifera). Contr. Sci. Los Angeles, 409: 1-75.

Hansen, H.J., 1890. Cirolanidae et familiae nonnullae propinque Musei Hauniensis. K. dansk. Vidensk. Selsk. Skr., nat. mat. Afd., (6) 5 (3): 237-426, pls. I-X.

Nierstrasz, H.F., 1930. Isopoda (excl. Oniscoidea et Epicaridea). Résultats scientifiques du voyage aux Indes Orientales Néerlandaises de LL. AA. RR. le Prince et la Princesse Léopold de Belgique. Mém. Mus. r. Hist. nat. Belg., (hors Série) 3 (1): 1-11.

Nierstrasz, H.F. \& J.W. de Marees van Swinderen, 1931. Süsswasser-Isopoden der Deutschen Limnologischen SundaExpedition. Arch. Hydrobiol., Suppl. 9 (Tropische Binnengewässer, 2): 394-402.

Riek, E.F., 1953. A corallanid isopod parasitic on freshwater prawns in Queensland. Proc. Linn. Soc. N.S.W., 77 (5-6): 259-261. 
Schioedte, J.C. \& F. Meinert, 1879. De Cirolanis Aegas simulantibus, commentatio brevis. Naturh. Tidsskr., (3) 12: 279-302, pls. III-IV.

Stebbing, T.R.R., 1907. A freshwater isopod from Calcutta. J. Linn. Soc., (Zool.) 30: 39-42, pl. 6.

Stebbing, T.R.R., 1908. Crustacea. A note on the genus Tachaea. Rec. Indian Mus., 2: 107.

Thielemann, M., 1910. Beiträge zur Kenntnis der Isopodenfauna Ostasiens. Abh. mat.-phys. Kl. bayer. Akad. Wiss.,
Suppl. 2 (3): 1-109, pls. I-II.

Weber, M., 1892. Die Süsswasser-Crustaceen des Indischen Archipels, nebst Bemerkungen über die Süsswasser-Fauna im Allgemeinen. In: M. Weber (ed.), Zoologische Ergebnisse einer Reise nach Niederländisch Ost-Indien, 2: 528-571, pl. XXX (E.J. Brill, Leiden).

Received: 22 January 1992 